OPEN ACCESS

Edited by:

Everett Meyer

Stanford University, United States

Reviewed by:

Suparna Dutt,

Stanford University, United States

Alexander Steinkasserer,

University Hospital Erlangen, Germany

*Correspondence:

Lilly Stahl

lilly.stah@@izi.fraunhofer.de

tThese authors have contributed equally to this work

¥These authors shared last authorship

Specialty section:

This article was submitted to Immunological Tolerance and Regulation,

a section of the journal

Frontiers in Immunology

Received: 30 November 2018 Accepted: 23 April 2019

Published: 24 May 2019

Citation:

Stahl L, Duenkel A, Hilger N, Tretbar US and Fricke S (2019) The Epitope-Specific Anti-human CD4 Antibody MAX.16H5 and Its Role in Immune Tolerance.

Front. Immunol. 10:1035 doi: 10.3389/fimmu.2019.01035

\section{The Epitope-Specific Anti-human CD4 Antibody MAX.16H5 and Its Role in Immune Tolerance}

\author{
Lilly Stahl ${ }^{1 * t}$, Anna Duenkel ${ }^{1 \dagger}$, Nadja Hilger ${ }^{2}$, Uta Sandy Tretbar ${ }^{1 \neq}$ and Stephan Fricke ${ }^{1 \neq}$ \\ ${ }^{1}$ Immune Tolerance Unit, Fraunhofer Institute of Cell Therapy and Immunology, Leipzig, Germany, ${ }^{2}$ Max-Bürger Research \\ Center, Institute for Clinical Immunology, University of Leipzig Medical Center, Leipzig, Germany
}

T cell modulation in the clinical background of autoimmune diseases or allogeneic cell and organ transplantations with concurrent preservation of their natural immunological functions (e.g., pathogen defense) is the major obstacle in immunology. An anti-human CD4 antibody (MAX.16H5) was applied intravenously in clinical trials for the treatment of autoimmune diseases (e.g., rheumatoid arthritis) and acute late-onset rejection after transplantation of a renal allograft. The response rates were remarkable and no critical allergic problems or side effects were obtained. During the treatment of autoimmune diseases with the murine MAX.16H5 $\operatorname{lgG}_{1}$ antibody its effector mechanisms with effects on lymphocytes, cytokines, laboratory and clinical parameters, adverse effects as well as pharmacodynamics and kinetics were studied in detail. However, as the possibility of developing immune reactions against the murine $\lg _{1} \mathrm{~F}_{\mathrm{c}}$-part remains, the murine antibody was chimerized, inheriting CD4-directed variable domains of the MAX.16H5 lgG 1 connected to a human $\lg _{4}$ backbone. Both antibodies were studied in vitro and in specific humanized mouse transplantation models in vivo with a new scope. By ex vivo incubation of an allogeneic immune cell transplant with MAX.16H5 a new therapy strategy has emerged for the first time enabling both the preservation of the graft-vs.-leukemia (GVL) effect and the permanent suppression of the acute graft-vs.-host disease (aGVHD) without conventional immunosuppression. In this review, we especially focus on experimental data and clinical trials obtained from the treatment of autoimmune diseases with the murine MAX.16H5 IgG 1 antibody. Insights gained from these trials have paved the way to better understand the effects with the chimerized MAX.16H5 lgG 4 as novel therapeutic approach in the context of GVHD prevention.

Keywords: T cell modulation, anti-human CD4 antibody, MAX.16H5, autoimmune disease, graft-vs.-host disease, graft-vs.-leukemia effect

\section{INTRODUCTION}

Besides the T cell receptor (TCR) and the CD3 antigen, other molecules are expressed on T cells but are also present on other hematopoietic cells (1). Monoclonal antibodies targeting such antigens (other than the TCR or CD3) can therefore bind to several antigen-expressing cell types. The CD4 molecule is expressed on T cells, monocytes and macrophages and contains four immunoglobulinlike domains (D1-D4) (2). It acts as a co-receptor during antigen presentation and associates with the TCR upon major histocompatibility complex $(\mathrm{MHC})$ binding $(1,2)$. In the past, several 
therapeutic strategies using CD4-directed antibodies were investigated for the treatment of several autoimmune diseases [reviewed in Wofsy (3) and Burmester et al. (4)]. In this context, the human $\mathrm{CD}^{+}$T-cell clone $2 \mathrm{C} 11$ was generated (5) for immunization of $\mathrm{BALB} / \mathrm{c}$ mice to produce the monoclonal antihuman CD4 antibody MAX.16H5 (initial name 30F16H5) $(6,7)$. Therefore, splenocytes of the immunized mice were fused with X63-Ag8.653 mouse myeloma cells to generate hybridoma cells (6-8). To examine their binding properties, antibody-containing hybridoma supernatants were incubated with $\mathrm{CD}^{+} \mathrm{T}$ cells prepared from peripheral blood $(\mathrm{PB})$ which were subsequently analyzed using enzyme-linked immunosorbent assays (ELISA) and cytofluorometric analyses (6). For the development as a therapeutic antibody, MAX.16H5 IgG 1 was selected because of its high affinity to CD4 (9). In this study, researchers compared 225 different CD4-directed antibodies regarding their CD4 binding properties and kinetics showing that MAX.16H5 IgG shared some fine specificities with gp120 with regard to the recognition of different mutated CD4 versions (9). At the same time, experiments were performed to obtain information about the binding properties of gp120 and MAX.16H5 IgG to the CD4 molecule by using peptides (10). The peptide $\mathrm{T}_{\mathrm{b}} \mathrm{YIC}_{\mathrm{b}} \mathrm{E}_{\mathrm{b}} \mathrm{VEDQK}_{\mathrm{Ac}} \mathrm{EE}$ was reported to inhibit CD4 binding of both gp120 and MAX.16H5 IgG 1 (10). During the early years, the antibody was tested in several different assays thereby obtaining solid information not only about antigen-binding properties, but also about antibody-mediated effector mechanisms. Throughout the clinical development of the murine MAX16.H5 $\mathrm{IgG}_{1}$, pharmacodynamic and pharmacokinetic data were collected. Upon administration in patients, the mode-of-action of the antibody, the induced CD4 and immunomodulation were studied intensively. Since MAX.16H5 IgG 1 was applied systemically, clinical data implementing cytokine profiles, acutephase-reactant evaluation and side effects were obtained and documented. This review summarizes the clinical development of the therapeutic use of MAX.16H5 $\mathrm{IgG}_{1}$ for the treatment of autoimmune diseases toward a promising

\footnotetext{
Abbreviations: AA, amino acid; ADCC, antibody dependent cellular cytotoxicity; aGVHD, acute graft-vs.-host disease; AML, acute myeloid leukemia; BW, body weight; CDC, complement dependent cytolysis; CEA, carcinoembryonic antigen; CRP, C-reactive protein; ELISA, enzyme-linked immunosorbent assay; ESR, erythrocyte sedimentation rate; $\mathrm{F}(\mathrm{ab})_{2}$, fragment antigen binding region; Fc, fragment crystallizable region; FcR, Fc receptor; FLT3, Fms like tyrosine kinase 3; FoxP3, forkhead box protein P3; GVHD, graft-vs.-host disease; GVL effect, graft-vs.-leukemia effect; HAMA, human anti-mouse antibody; HIV, human immunodeficiency virus; HLA, human leukocyte antigen; HSC, hematopoietic stem cell; HSCT, hematopoietic stem cell transplantation; IBD, inflammatory bowel disease; Ig, immunoglobulin; IL, interleukin; ITD, internal tandem duplication; ITAM, immunoreceptor tyrosine-based activating motif; ITIM, immunoreceptor tyrosine-based inhibitory motif; i.v., intravenous; JCA, juvenile chronic arthritis; Lck, lymphocyte-specific protein tyrosine kinase; mAb, monoclonal antibody; LPS, lipopolysaccharide; MHC, major histocompatibility


peripheral blood mononuclear cell; PD-1, programmed cell death protein 1; PD-L1, programmed cell death 1 ligand 1; PHA, phytohemagglutinin; p.i., post injection; RA, rheumatoid arthritis; RF, rheumatoid factor; sCD14, soluble CD14; SLE, systemic lupus erythematosus; TCR, T-cell receptor; $\mathrm{T}_{\mathrm{h}}$ cell, T-helper cell; $\mathrm{T}_{\text {reg }}$, regulatory $\mathrm{T}$ cell; $\mathrm{TT}$, tetanus toxoid.
}

treatment option for hematopoietic stem cell transplantation (HSCT)-related GVHD.

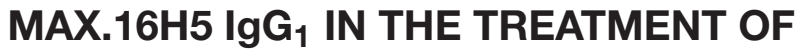 AUTOIMMUNE DISEASES}

In total, 47 patients have been treated with the murine wild type antibody MAX.16H5 $\operatorname{IgG}_{1}(7,11-24)$. The individuals suffered from varying diseases or conditions: rheumatoid arthritis (RA), systemic lupus erythematosus (SLE), inflammatory bowel disease (IBD), or acute late-onset rejection after transplantation of a renal allograft (Table 1). Thereby, RA was the most studied disease. Besides the studies focusing on the applicability of MAX.16H5 $\mathrm{IgG}_{1}$ as a promising therapeutic antibody format, several studies were published about the use of ${ }^{99 m}$ Tc-labeled MAX.16H5 IgG in RA patients to report the localization/accumulation, the pharmacokinetics, and the elimination process of the antibody $(7,11,23,24)$. A broad variety of parameters was obtained during these clinical trials to evaluate the safety and efficacy of the systemic therapeutic administration of MAX.16H5 IgG 1 . Table $\mathbf{1}$ provides an overview of the studies performed in humans.

Since it is known that murine antibodies can cause immunological reactions in humans, the administration of the murine MAX.16H5 IgG 1 was particularly examined. Immunological reactions against the Fc-part of the murine antibody were expected, and in three different studies that administered MAX.16H5 $\mathrm{IgG}_{1}$ in the background of RA the production of human anti-mouse antibodies (HAMAs) was investigated $(13,16,21)$. Based on the obtained datasets authors concluded that HAMA production followed by MAX.16H5 IgG administration was rather low and that HAMA activities are directed against specific determinants of the antibody, including anti-idiotypic reactivity (16). Furthermore, it was shown that MAX.16H5 IgG $\mathrm{F}(\mathrm{ab})_{2}$ directed HAMA (IgG) levels did not exceed levels higher than $0.7 \mathrm{mg} / \mathrm{l}$ after the first and $1.7 \mathrm{mg} / \mathrm{l}$ after the second course of therapy (13). Compared to HAMA activities exceeding $100 \mathrm{mg} / \mathrm{l}$ measured in other studies using monoclonal murine antibodies against cancer antigens $(25,26)$ in immunocompetent patients, the HAMA amounts directed against MAX.16H5 IgG 1 were rather low, but detectable. Overall, even in studies using the murine $\operatorname{IgG}_{1}$ isotype of MAX.16H5, only low HAMA amounts were detected which allowed for further treatment cycles without loss of efficacy (16).

\section{MAX.16H5 IgG 1 Mediated Effector Mechanisms}

Antibodies can mediate effector mechanisms by both binding the antigen via the Fab domain and binding Fc receptors (FcRs) expressed on effector cells through the Fc part. Mouse $\operatorname{IgG}_{1}$ is known to bind two different murine $\mathrm{Fc}$ receptors, $m F c \gamma R I I b$ and $m F c \gamma R I I I$ (27). The $m F c \gamma R I I b$ is an immunoreceptor tyrosine-based inhibitory motif (ITIM)carrying receptor, which is highly expressed on murine B cells, granulocytes, macrophages, monocytes and dendritic cells (27). In contrast, $\mathrm{mFc} \gamma \mathrm{RIII}$ is absent on $\mathrm{B}$ cells but highly expressed on monocytes, macrophages, dendritic cells, and granulocytes 
TABLE 1 | Results of human studies using MAX.16H5 $\mathrm{lgG}_{1}$.

\begin{tabular}{|c|c|c|c|c|c|}
\hline $\begin{array}{l}\text { Underlying } \\
\text { disease }\end{array}$ & $N$ & MAX.16H5 IgG 1 treatment & RR & Adverse effects and HAMA development & References \\
\hline
\end{tabular}

\begin{tabular}{|c|c|c|}
\hline Active, severe RA & 6 & $\begin{array}{l}5 / 6 \text { patients: } 200-300 \mu \mathrm{g} \text { iv }(370-550 \mathrm{MBq}) \\
99 \mathrm{~m} T \mathrm{~T}-\mathrm{mAb} \\
1 / 6 \text { patients: } \geq 10 \mathrm{MBq} \text { of lymphocytes } \\
\text { treated in vitro with }{ }^{99 \mathrm{~m}} \mathrm{Tc}-\mathrm{mAb}\end{array}$ \\
\hline Active, severe RA & 10 & $\begin{array}{l}0.3 \mathrm{mg} / \mathrm{kg} \mathrm{BW}[20 \mathrm{mg} / \text { day }(14)] \text { iv on } 7 \\
\text { consecutive days; repeated treatment cycle } \\
\text { after } 8 \text { weeks ( } 4 / 10 \text { patients) }{ }^{\mathrm{a}}\end{array}$ \\
\hline
\end{tabular}

n.r. No adverse effects observed

1/6 patients: $\geq 10 \mathrm{MBq}$ of lymphocytes

treated in vitro with ${ }^{99 \mathrm{~m}} \mathrm{Tc}-\mathrm{mAb}$

after 8 weeks $\left(4 / 10\right.$ patients) ${ }^{a}$

9/10 $2 / 10$ patients: chills with fever, possibly due to lymphokine release syndrome (13)

2/10 patients: urticaria, $1 / 2$ with severe allergic reaction possibly triggered

$(13-16)(19)$

by keeping a rodent as a pet, patient withdrawn from study (13)

Chills, tremor, elevated body temperature, and nausea (15) Systemic side

effects correlated with elevated levels of TNF- $\alpha$, IL-2, and IFN- $\gamma$ (15)

5/10 patients: HAMA production after 1 st treatment cycle $\rightarrow$ of these $3 / 4$ showed HAMA production after 2nd treatment cycle (16)

\begin{tabular}{|c|c|c|}
\hline $\begin{array}{l}\text { Chronic active } \\
\text { steroid-resistant or } \\
\text { steroid-dependent } \\
\text { IBD }\end{array}$ & 3 & $0.3 \mathrm{mg} / \mathrm{kg}$ BW iv on 7 consecutive days ${ }^{\mathrm{c}}$ \\
\hline $\begin{array}{l}\text { Severe acute } \\
\text { rejection after renal } \\
\text { allograft }\end{array}$ & $11^{\mathrm{e}}$ & $\begin{array}{l}\text { 5/11 patients: } 0.6 \mathrm{mg} / \mathrm{kg} \mathrm{BW} \text { iv on } 3 \\
\text { consecutive days }^{\mathrm{e}}\end{array}$ \\
\hline $\begin{array}{l}\text { Intractable severe } \\
\text { SLE }\end{array}$ & 1 & $0.3 \mathrm{mg} / \mathrm{kg}$ BW iv on 7 consecutive days ${ }^{f}$ \\
\hline Active, severe RA & 4 & $\begin{array}{l}3 / 4 \text { patients: } \leq 250 \mu \mathrm{g}^{99 \mathrm{~m}} \mathrm{Tc}-\mathrm{mAb} \mathrm{iv}^{\mathrm{h}} 1 / 4 \\
\text { patients: } \geq 10 \mathrm{MBq} \text { of lymphocytes treated } \\
\text { in vitro with }{ }^{99 \mathrm{~m}} \mathrm{Tc}-\mathrm{mAb} \mathrm{b}^{\mathrm{h}}\end{array}$ \\
\hline $\begin{array}{l}\text { Active, severe RA } \\
\text { or healthy control }\end{array}$ & 8 & $\begin{array}{l}\text { 200-300 } \mu \mathrm{g}(370-550 \mathrm{MBq})^{99 \mathrm{~m}} \mathrm{Tc}-\mathrm{mAb} \\
\text { and/or } 1 \mathrm{mg}(370 \mathrm{MBq}) \text { iv polyclonal HIG }\end{array}$ \\
\hline Active, severe RA & 1 & 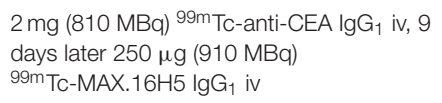 \\
\hline $\begin{array}{l}\text { Active, severe } \\
\text { systemic onset } \\
\text { JCAF }\end{array}$ & 2 & $\begin{array}{l}2 \text { courses of } 0.3 \mathrm{mg} / \mathrm{kg} \mathrm{BW} \text { iv on } 7 \\
\text { consecutive days (time interval: } 8 \text { weeks) }\end{array}$ \\
\hline "adult type" RA & 1 & $\begin{array}{l}\text { single course of } 0.3 \mathrm{mg} / \mathrm{kg} \mathrm{BW} \text { iv on } 7 \\
\text { consecutive days }\end{array}$ \\
\hline
\end{tabular}

3/3 $\quad$ No adverse effects observed

$3 / 5^{e} \quad$ No adverse effects reported

1/19 No adverse effects observed

n.r. No adverse effects observed

n.r. No adverse effects reported

n.r. No adverse effects reported

3/3 $\quad$ No side effects after first treatment course

1/2 JCA patients: urticarial rash after first infusion of the second course

1/2 JCA patients: fever up to $39.5^{\circ} \mathrm{C}$ with chills after the first antibody infusion of the second course

Further infusions of the second treatment course well tolerated HAMA

development detected in both JCA patients after two treatment courses

No alterations in organ function, no infections observed either during

treatment or during a 6months follow up in JCA patients

No side effects reported for third patient with "adult type" RA

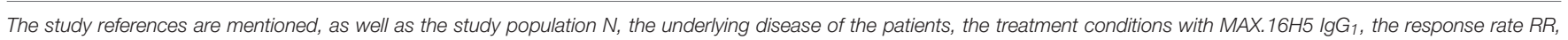
and-if so-observed adverse effects and HAMA development.

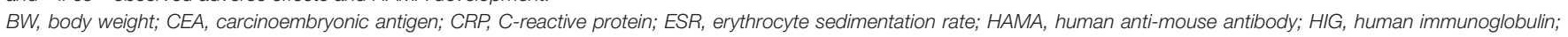

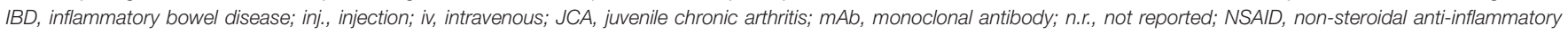
drug; $R A$, rheumatoid arthritis; $R R$, response rate; SLE, systemic lupus erythematosus.

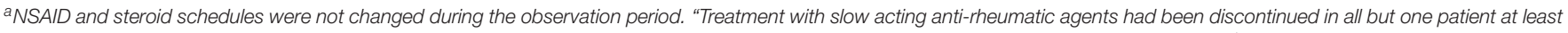
8 weeks before treatment" (18). Low-dose cyclophosphamide (50 mg/day) was maintained in one patient. Analysis of HAMA production in a $2^{\text {nd }}$ treatment cycle after 6-8 weeks (16).



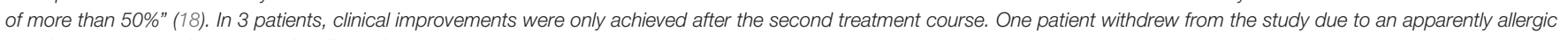
reaction and was excluded from the discussion.

${ }^{c}$ Aside from the antibody treatment, $1.5 \mathrm{~g}$ (2 patients) or $3 \mathrm{~g}$ (1 patient) mesalazine were given together with $10 \mathrm{mg}$ prednisolone throughout the observation period.

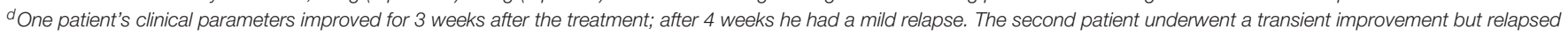
after 1 month. The last patient had a complete clinical, endoscopic, and biochemical remission for more than 5 months.

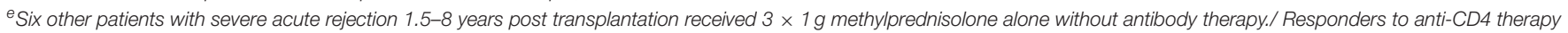
were characterized by creatinine levels below $50 \%$ of maximum increase 4 weeks after rejection treatment.

${ }^{f}$ Prednisolone therapy (50 mg/day) was continued throughout the observation period.

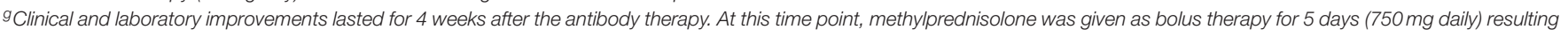
in complete remission proven by the (for the first time) negative anti-DNA-antibody titer.

h "Four weeks before scintigraphy, conventional anti-inflammatory therapy was stopped whereas ongoing steroid treatment was continued with <10 mg/d" (11).

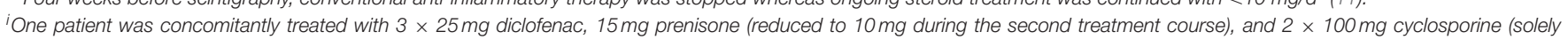

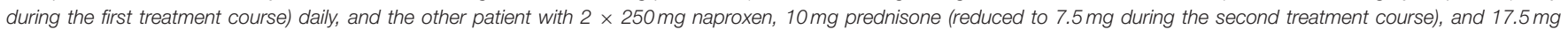
methotrexate daily.

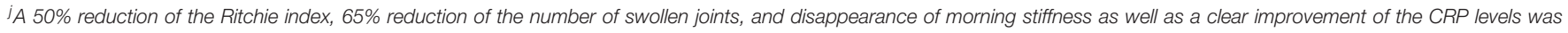

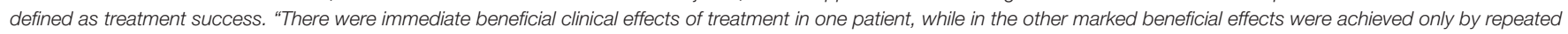

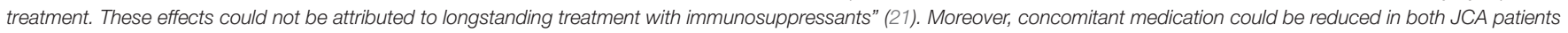
after the first treatment course.
} 
thereby mediating activating signals via an immunoreceptor tyrosine-based activation motif (ITAM) [reviewed in Bruhns (27)]. Mice produce three different IgG subclasses which do not only differ in their FcR binding specificity but also bear diverse capacity to activate the complement system (27-30). Based on serum bactericidal activity measurements the following hierarchy of murine IgG induced complement activity was proposed: IgG3 $>\operatorname{IgG} 2>\operatorname{IgG} 1$ (30). It has to be noted that in these assays human serum was used as a source of complement (30).

To this date, no MAX.16H5 $\mathrm{IgG}_{1}$ mediated complementdependent cytotoxicity (CDC) (using rabbit serum as a source of complement) or antibody-dependent cell-mediated cytotoxicity (ADCC) using granulocytes or peripheral blood monocytes as effector cells was obtained in in vitro assays $(13,31)$.

\section{Effects on Lymphocytes}

In general, the MAX.16H5 IgG 1 treatment results in a decrease of $\mathrm{CD}^{+}$cells in RA patients and therefore to an overall reduction of $\mathrm{CD}^{+}$cells $(13,14)$. Neither $\mathrm{CD}^{+}$nor $\mathrm{B}$-cell values were changed in RA patients $(13,14)$. Immune cells from RA patients treated with MAX.16H5 IgG $_{1}$ showed reduced proliferation to various stimulatory agents $1 \mathrm{~h}$ post injection (p.i.) (13). However, in four out of nine patients, increased mitogen responses were induced after 8 days, which was indicative for unaltered clinical effects in these patients (13). Blood samples from IBD patients treated with MAX.16H5 IgG 1 showed a reduced lymphocyte proliferation after stimulation with mitogens and recall antigens (20), too.

Immortalized and interleukin (IL)-2-dependent $\mathrm{CD} 4^{+} \mathrm{T}$ cells revealed reduced mitotic activity (not increased apoptosis) after incubation with MAX.16H5 IgG 1 or its $F\left(a^{\prime}\right)_{2}(32)$. The same effect was observed with the Fab of MAX.16H5 and gp120 of HIV which could be prevented by high concentrations of IL2 (32). The authors showed that this effect was connected to a decreased amount of lymphocyte-specific protein tyrosine kinase (Lck) bound to the intracellular domain of CD4 (32).

For further investigation of intracellular signaling pathways, the calcium release after TCR stimulation was examined in peripheral blood mononuclear cells (PBMCs) of RA patients or healthy donors treated with MAX.16H5 $\operatorname{IgG}_{1}(33,34)$. In one study, samples from healthy donors showed reduced intracellular calcium levels after MAX.16H5 IgG 1 incubation and TCR stimulation in vitro, but only if MAX.16H5 IgG 1 was still bound to the CD4 molecule (33). In a second study, the intracellular calcium concentration did not increase after solely incubation with MAX.16H5 IgG 1 (34). Only after cross-linking of CD3 and CD4 by anti-mouse goat serum an increased intracellular calcium signaling was obtained if MAX.16H5 incubation was performed for a maximum of $5 \mathrm{~min}$ (34). For longer incubation periods, the calcium signal decreased again indicating that full $\mathrm{T}$ cell activation by CD3 occurs rapidly within a short time (34). These data indicate a strong dependence of preincubation time. Furthermore, the increased calcium release only after crosslinking of CD3 and CD4 leads to the following speculation: the T cell activation was impaired due to transient but asynchronous activity of different kinases in T cells and intercellular cross-talk between $\mathrm{T}$ cells and monocytes was required (34).
At the time the studies were conducted, regulatory $\mathrm{T}$ cells $\left(\mathrm{T}_{\text {regs }}\right)$ were not yet identified as important targets to follow in clinical GVHD research: By 2000, $T_{\text {regs }}$ were identified as suppressors of autoimmunity in vitro and in mouse models [reviewed in Shevach (35) and Sakaguchi (36)]. However, the flow cytometric identification of $\mathrm{T}_{\text {regs }}$ remained difficult until they were specified as positive for CD4, CD25, and forkhead box protein P3 (FoxP3) in 2003 (37-39). Therefore, the clinical data on MAX.16H5 $\mathrm{IgG}_{1}$ lack information on the $\mathrm{T}_{\text {reg }}$ population.

\section{Effects on B-Cell Crosstalk With T-Helper Cells and Immunoglobulin Secretion}

PBMCs of healthy individuals were assessed for effects of MAX.16H5 IgG $\mathrm{Ig}_{1}$ incubation on B-cell differentiation and resulting $\operatorname{IgG}$ and $\operatorname{IgM}$ production (40). It was found that incubation with MAX.16 $5 \mathrm{IgG}_{1}$ inhibited B-cell differentiation and following immunoglobulin (Ig) production (40). Even in the presence of mitogens and IL-2 or IL-4, MAX.16H5 IgG addition reduced Ig secretion (40). Moreover, the production of IL-2 and IL- 4 by T-helper $\left(\mathrm{T}_{\mathrm{h}}\right)$ cells was minimally influenced by MAX.16H5 IgG 1 under various stimulating conditions (40). Thus, cytokines were not responsible for lower Ig secretion after MAX.16H5 incubation. More likely, the reduction of direct cellular contacts between $\mathrm{T}_{\mathrm{h}}$ and $\mathrm{B}$ cells by MAX.16H5 IgG and its $\mathrm{F}(\mathrm{ab})_{2}$ lead to reduced crosstalk between the two cell types causing reduced Ig secretion indicating that CD4-blockade by MAX.16H5 interferes with early T-B cell collaboration (40). In RA patients, Ig reduction was observed after MAX.16H5 $\mathrm{IgG}_{1}$ treatment, especially rheumatoid factor (RF) production, indicating that this effect is also present in vivo (13).

\section{Effects on Monocytes}

In the treatment of RA with MAX.16 $5 \mathrm{IgG}_{1}, \mathrm{CD} 14^{+}$monocytes in the $\mathrm{PB}$ were reduced one hour after infusion of MAX.16H5 $\mathrm{IgG}_{1}$ (13). Continuing the MAX.16H5 IgG 1 treatment kept monocyte levels in normal ranges (13). The authors offer two possible explanations: either the monocyte/macrophage system is responsible for the depletion of antibody-coated $\mathrm{T}$ cells or the MAX.16H5 $\mathrm{IgG}_{1}$ bound to the CD4 molecule present on a monocyte subset results in temporary monocyte reduction in the PB (13). On the other hand, reduced crosstalk between $\mathrm{T}_{\mathrm{h}}$ cells and monocytes may play a role in the observed reduction of monocyte activation (13). In different studies, the same RA patients were monitored for monocyte activation indicated by heightened neopterin serum values, MHC class II expression, monocyte counts, and IL-1 production prior to MAX.16H5 $\mathrm{IgG}_{1}$ application (14). These parameters could be reduced after MAX.16H5 $\mathrm{IgG}_{1}$ treatment (14). Moreover, elevated levels of soluble CD14 (sCD14) detected in five patients prior to MAX.16H5 $\mathrm{IgG}_{1}$ treatment were reduced in three patients after antibody application (18). IL-1 and IL-6 serum levels correlated to sCD14 concentrations in RA patients (18). A comparison between therapy responders and non-responders revealed reduced monocyte and $\mathrm{T}_{\mathrm{h}}$ cell counts in the responder group, whereas both values increased again in the non-responder group after 1 week (18). 


\section{Cytokine Release}

In chronic inflammatory diseases such as RA and SLE, the release of pro-inflammatory cytokines plays a crucial role in disease progression. Elevated levels of cytokines produced by $\mathrm{CD} 4^{+}$ cells including tumor necrosis factor (TNF)- $\alpha$, IL-1, IL-6, and IL-17 favor disease pathogenesis [reviewed in Lourenço and La Cava (41) and McInnes and Schett (42)]. Monoclonal antibodies (mAbs) against these molecules or their respective receptors are therapeutic options to treat patients with autoimmune diseases (43). Therefore, the effect of the treatment with MAX.16H5 $\mathrm{IgG}_{1}$ targeting human $\mathrm{CD}^{+}{ }^{+}$cells regarding cytokine release was studied in detail in vivo and in vitro.

IL-6 is known as the most important inducer and regulator of acute-phase response (44). Elevated IL-6 levels were measured in most RA patients before MAX.16H5 treatment (18). The IL6 levels rapidly declined in four patients during the treatment course, which was observed in parallel with substantial clinical and laboratory improvement (18). On the other hand, one patient showed a slight increase of IL-6 during first treatment course and did not respond to treatment (18). One individual demonstrated a considerable increase of IL-6 and underwent an allergic skin reaction after the first injection (18). In that special patient, the IL- 6 levels decreased to the pretreatment values after the treatment was stopped (18).

Besides the positive effect of IL- 6 reduction, cytokine release due to MAX.16H5 IgG 1 application was analyzed as potential side effect. During the therapy of RA patients with MAX.16H5 $\mathrm{IgG}_{1}$, symptomatic patients showed elevated serum levels of TNF- $\alpha$, IFN- $\gamma$, and/or IL-2 (15). Comparison of the modulation efficacy of $\mathrm{CD} 4{ }^{+} \mathrm{T}$ cells induced by MAX.16H5 treatment did not reveal any difference between patients without clinical adverse effects and those developing systemic side effects (15). The authors hypothesized that the clinical adverse effects were likely a result of lymphocyte activation and/or a monocyte/macrophage interaction with lymphocytes (15). A comparable side effect profile was described for mAb OKT3 treatment $(45,46)$ but MAX.16H5 IgG 1 induced effects were milder and of much shorter duration which made a further treatment of the patient unnecessary (15). It has to be noted, that only a small cohort of patients systemically received MAX.16H5 $\mathrm{IgG}_{1}$ therapy for autoimmune disease treatment, which complicates drawing solid conclusions.

The cytokine production in SLE patients was analyzed in vitro as well (47). Spontaneous IL-6 secretion was heightened in blood cell cultures from patients with active SLE compared to cultures from inactive SLE patients and healthy controls (47). After incubation with MAX.16H5 $\mathrm{IgG}_{1}$, cell cultures of active SLE patients demonstrated reduced IL-6 levels, whereas TNF- $\alpha$ levels were not significantly altered (47). When samples from healthy volunteers were stimulated either with phytohemagglutinin (PHA) or lipopolysaccharide (LPS) MAX.16H5 IgG 1 induced IL-6 decrease was found to be antibody dose-dependent (47). In control wells it was shown that the addition of methylprednisolone to the cell cultures of stimulated healthy volunteer samples, stimulated inactive SLE samples and unstimulated active SLE samples not only reduced IL- 6 but also TNF- $\alpha$ secretion markedly (47). Summarized it was shown that MAX.16H5 antibody incubation altered stimulated IL-6 secretion of in vitro blood cell cultures obtained from SLE patients and healthy individuals. The decrease of stimulated IL6 secretion was dose-dependent. Other than methylprednisolone MAX.16H5 IgG 1 incubation did not influence TNF- $\alpha$ levels in these assays (47).

\section{Laboratory and Clinical Parameters}

In contrast to other anti-CD4 antibodies, MAX.16H5 was the only one improving not only clinical but also laboratory parameters in RA patients [reviewed in Burmester and Emmrich (48)]. Additionally, MAX.16H5 application showed an effect on parameters which were associated with monocyte/macrophage activation (14). In general, a significant decrease of laboratory [erythrocyte sedimentation rate (ESR), RF titer, C-reactive protein (CRP) levels] and clinical parameters (Ritchie articular index and swollen joints) was observed (13). In one of the patients, no impact on ESR and CRP levels was observed during the first cycle of MAX.16H5 infusion (17). Four years before the treatment with MAX.16H5 IgG 1 , the patient was diagnosed with RA. Due to a trauma, he underwent splenectomy earlier in life (17). After the second course of MAX.16H5 therapy, ESR and CRP levels were reduced, possibly followed after decreased IL6 serum values (17). Since the change in laboratory variables did not translate into an improvement of clinical parameters, low dose chlorambucil was implemented into the treatment regimen. The combination of CD4 directed antibody therapy together with chemotherapeutic medication resulted in clinical improvements which also translated in continued reduced levels of certain inflammatory parameters (ESR and CRP) (17). Overall, no adverse effects (especially infections) were observed (17).

The clinical parameters of two children were assessed in another study where MAX.16H5 was given i.v. for treatment of refractory juvenile chronic arthritis (JCA) (21). One patient benefited from the antibody therapy clinically within 1 week after the first antibody application. A second antibody application showed an even more improved response compared to the first course of treatment and symptoms like fever and rash were reduced for around 2 months (21). In the second patient, two cycles of treatment were needed to obtain notable improvement of clinical symptoms. Also, these juvenile patients did not show any signs of adverse side effects caused by the MAX.16H5 IgG antibody treatment (21).

Patients suffering from severe acute rejection after kidney transplantation also benefitted from the therapy with MAX.16H5 $\operatorname{IgG}_{1}$ (22). Histological signs of acute rejection (if present) disappeared as a response to the MAX.16H5 $\mathrm{IgG}_{1}$ treatment. All patients showed rapid decreasing serum creatinine levels within the first 3 days post injection. However, graft function was impaired in two patients 3-4 weeks after therapy and one patient experienced transplant rejection again after 10 weeks (22). The authors observed a rapid effect of the MAX.16H5 antibody in the treatment of acute rejection after kidney transplantation and concluded that $\mathrm{CD} 4^{+} \mathrm{T}$ cells seem to play an important role in the rejection process. They further suggested to implement the antibody therapy in established immunosuppression treatment protocols to improve therapeutic efficacy (22).

MAX.16H5 $\mathrm{IgG}_{1}$ application was also shown to be effective in the treatment of inflammatory bowel disease (IBD) (20). 
Especially, when other treatment options are exhausted and conventional therapeutics are ineffective MAX.16H5 IgG $_{1}$ can be used as a treatment option in IBD (20). As also discussed in the treatment of autoimmune diseases earlier, single cycle administration of MAX.16H5 was insufficient to reach persistent therapeutic success (20).

\section{Other Effects}

Since the exact mechanism of the MAX.16H5 IgG 1 induced effects were not sufficiently explained neither in vitro nor in vivo, researchers focused on the intracellular signaling after antibody binding to its antigen. By using U937 target cells, the activation of complex inositol polyphosphate responses and $\mathrm{Ca}^{2+}$ increase after MAX.16H5 IgG 1 antibody treatment was investigated in vitro independently from TCR signaling (49). The authors

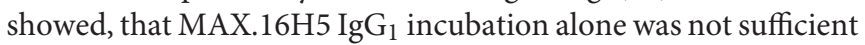
to induce $\mathrm{Ca}^{2+}$ increase in CD4-expressing cells (PB-monocytes and the monocyte cell line U937) (49). When goat anti-mouse antiserum was added, clear crosslinking of MAX.16H5 IgG 1 was obtained leading to heightened $\mathrm{Ca}^{2+}$ levels (49). The outcome of experiments in U937 cells using $\mathrm{F}(\mathrm{ab})_{2}$ fragments of MAX.16H5 together with $\mathrm{F}(\mathrm{ab})_{2}$ crosslinking agents were not applicable to observations made with whole antibodies (49). The authors concluded that in U937 cells only "[... ] crosslinking of CD4 and $\mathrm{Fc} \gamma \mathrm{R}$, but not cross-linking of CD4 alone specifically activates the inositol polyphosphate/ $\mathrm{Ca}^{2+}$ signal transduction pathway" (49).

\section{Pharmacokinetics and Pharmacodynamics in Humans}

Pharmacokinetic and pharmacodynamic studies with ${ }^{99 \mathrm{~m}} \mathrm{Tc}$ labeled MAX.16H5 $\operatorname{IgG}_{1}$ were performed in RA patients $(7,11$, $23,24)$. In one study, patients received either i.v. injection of ${ }^{99}$ Tc-labeled MAX.16H5 $\mathrm{IgG}_{1}$ antibody or ex vivo ${ }^{99 \mathrm{~m}} \mathrm{Tc}$-labeled MAX.16H5 IgG 1 incubated PB-lymphocytes (7). Following images/scans were taken using a gamma camera (7). The use of the CD4-directed MAX.16H5 IgG 1 antibody for medical imaging in order to obtain information about disease progression in RA or also for diagnosis was promising since techniques used at that time, e.g., ${ }^{99 \mathrm{~m}} \mathrm{Tc}$-early methylene diphosphonate (MDP) bone scans, were rather unsatisfactory (7). The authors concluded that ${ }^{99 \mathrm{~m}}$ Tc-labeled MAX.16H5 imaged the localization of disease joints more precisely than MDP scans, which made it a promising tool for the diagnosis of autoimmune arthritis (7).

\section{Organ Activity Distribution and Kinetics}

In context with their participation in a therapeutic trial for RA [preliminary data after 2 patients enrolled evaluated in (50)], 4 patients received either radio-labeled MAX.16.H5 $\mathrm{IgG}_{1}$ antibody i.v. or PB-lymphocytes labeled with the antibody [1 patient] (11). The "[...] study was mainly concerned with the evaluation of the kinetic behavior of the antibody-labeled cells in the patients" (11). In general, the maximum of activity [100\%] of the antibody or the antibody-labeled lymphocytes was reached within a few minutes in the heart and lung (ca. $4.5 \mathrm{~min}$ ), whereas the maximum of radio-labeled activity was obtained after ca. $12 \mathrm{~min}$ in the spleen and about $19 \mathrm{~min}$ in the liver (11). However, $90 \mathrm{~min}$ after the injection, radiolabeled MAX.16H5 antibody activity reincreased in the patients' hip joints after a first injection peak (11). Interestingly, organ kinetic curves were comparable between patients receiving ${ }^{99 \mathrm{~m}} \mathrm{Tc}$-labeled MAX.16H5 $\mathrm{IgG}_{1}$ and the patient who received ex vivo antibody-labeled lymphocytes (11). Additionally, study examined the whole-body radioactivity distribution at two different time points [ 4 and $24 \mathrm{~h}$ p.i.] (11). "The splenic uptake decreased by about $39 \%$ from $4 \mathrm{~h}[\ldots]$ to $24 \mathrm{~h}$ p.i. [...]" (11). A moderate increase of activity measured in the liver was recorded (11). Nevertheless, at both time points, approximately $50 \%$ of radioactivity was measured in the bone marrow. Joints overall showed a rather low activity with $0.5 \pm$ $0.09 \%$ for not-diseased joints vs. 2 (after $4 \mathrm{~h}$ ) to $2.5 \%$ (after $24 \mathrm{~h}$ ) for a single affected joint (11).

Another study (23) evaluated the kinetic differences between labeled MAX.16H5 IgG 1 and polyclonal human immunoglobulin (HIG) in RA patients or healthy controls to exclude non-specific accumulation of immunoglobulin. Compared to HIG, ${ }^{99 \mathrm{~m}} \mathrm{Tc}$ labeled MAX.16H5 IgG 1 showed a higher uptake in the liver and in the spleen of RA patients at $24 \mathrm{~h}$ p.i. (23). Since the MAX.16H5 IgG $_{1}$ "[...] showed a higher target-to-background ratio in arthritic knee and elbow joints in comparison to polyclonal HIG used for conventional imaging [... ]" the authors discussed a potential beneficial application of the antibody in the "[...] detection of inflammatory infiltrates rich in CD4-positive cells" (23).

\section{Adverse Effects}

The adverse effects observed in studies with human patients or healthy volunteers are summarized in Table 1. In different trials using the ${ }^{99 \mathrm{~m}} \mathrm{Tc}$-labeled MAX.16H5 $\mathrm{IgG}_{1}$, no adverse reaction was observed after the intravenous application $(7,11,23,24)$.

Several studies examined the treatment of RA patients with MAX.16H5 $\mathrm{IgG}_{1}$. In general, only occasional and minor side effects were observed which probably resulted from short lived cytokine peaks (15). The infusions were well-tolerated [reviewed in Burmester and Emmrich (48)]. Immediate adverse effects were allergic reactions on rare occasion as well as nausea and fever being symptomatic for the development of a mild to moderate cytokine release syndrome (15). A long-term effect on the topic of laboratory parameters was the development of HAMAs $(13,16,21)$. Approximately $25 \%$ of the HAMA activity was directed against idiotypic determinants (16). Significant HAMA concentrations were measured between 2 and 12 weeks p.i. (16). Still, in contrast to monoclonal antibodies directed against other $\mathrm{T}$ cell epitopes, the amounts of these antibodies were low and never exceeded 2.0 (after 1 cycle) or $2.2 \mathrm{mg} / 1$ (after 2 cycles) (16). Thus, patients could be retreated without loss of efficacy (13) as similarly shown with other anti-human CD4 antibodies (51).

The reduced $\mathrm{CD} 4^{+} \mathrm{T}$ cell numbers did not result in infectious problems in any study (48). Together with an unaltered or even elevated $\mathrm{T}$ cell reactivity in vitro [4 patients showed heightened $\mathrm{T}$ cell reactivity to common antigens and mitogens when $\mathrm{CD} 4^{+}$ cell numbers were still reduced (13)], this observation points to low numbers of $\mathrm{CD}^{+} \mathrm{T}_{\mathrm{h}}$ cells being sufficient to maintain the function of the cellular immune system $(13,48)$.

In the trial using MAX.16H5 $\mathrm{IgG}_{1}$ in the treatment of refractory JCA in two patients the first treatment course was 
tolerated without side effects (21). Application of MAX.16H5 $\mathrm{IgG}_{1}$ in the treatment of either SLE or IBD patients did not show any side or adverse effect $(12,20)$. In the therapy of acute rejection in long-term renal allograft recipients, no adverse effects due to the treatment were mentioned in the original article (22).

Although not all trials showed the development of HAMAs as side effect, the possibility of developing immune reactions against the murine $\operatorname{IgG}_{1}$ Fc-part remains. This risk was considered to be reduced by the development of a chimerized, humanized version of the MAX.16H5 $\mathrm{IgG}_{4}$ antibody.

\section{DEVELOPMENT OF A CHIMERIZED MAX.16H5 $\operatorname{lgG}_{4}$ MONOCLONAL ANTIBODY}

The use of murine antibody formats for therapeutic interventions was shown to be connected to the development of several side effects, e.g., antibody responses (HAMA) or allergic reactions, which led to the development of optimization protocols in antibody design using recombinant DNA tools already in the 1980's (52, 53). Morrison et al. described a process called "chimerization" where heavy and light chain variable DNA sequences of a murine antibody were connected to DNA sequences encoding human $\operatorname{IgG}_{1 / 2}$ and sequences encoding for the human kappa light chain, respectively (53). Morrison and colleagues discussed the potential of such "near-human" antibody formats with respect to reduced side effect profiles when administered in vivo (53). In 1997, the approval of rituximab, a chimeric CD20-directed $\mathrm{IgG}_{1}$ antibody for the treatment of lymphoma eventually paved the way for modified antibody formats (54). In December 2018, 75 antibodies as therapeutics were approved for the treatment of a variety of diseases including 9 antibodies carrying human $\mathrm{Fc}$ domains and murine variable sequence motifs and are therefore defined as chimeric (43). The aforementioned CD20-directed antibody rituximab is listed as well as e.g., obiltoxaximab, which reached US-approval more recently (2016) and is used for the treatment and prophylaxis of inhalational anthrax (55). The chimerization of MAX.16H5 was promoted in order to reduce immunogenicity of the antibody for potential clinical applications. The MAX.16H5 chimerization process was started in 2007. A CD4-directed murine $\operatorname{IgG}_{1}$ antibody-expressing hybridoma clone was used as starting material. By combining cloning and sequencing techniques together with in silico modeling, variable regions of light and heavy chains were extracted, analyzed, modified and connected to human constant regions as commissioned (Figure 1) (56). Mammalian cells were used for the production of the chimeric antibody (56). Binding profiles of MAX.16H5 IgG were comparable with the murine MAX.16H5 $\mathrm{IgG}_{1}$ proving that the correct variable regions were chosen to generate the chimeric antibody (56).

In general, Fc parts of antibodies are known to mediate effector mechanisms which include their interaction with both certain Fc receptors expressed on effector cells and the activation of the complement system (57). Depending on their Fc-binding capacities and mediated effector mechanisms, therapeutic antibodies can be used for different therapeutic purposes. In the setting of HSCT or GVHD, an Fc-mediated depletion of $\mathrm{CD}^{+}{ }^{+}$cells was not our desired therapeutic approach. Therefore, MAX.16H5 variable domains were specifically connected to human $\mathrm{IgG}_{4}$ and not to human $\mathrm{IgG}_{1}$ constant domains since it is known that $\mathrm{IgG}_{4}$ is a weak activator of ADCC and CDC (58) [reviewed in Davies and Sutton (59)]. Because of the functional features of the $\mathrm{IgG}_{4}$ isotype, its translation into the clinical application in the field of immune checkpoint blockade was quite successful. To date, pembrolizumab (MK3475) and nivolumab (MDX-1106), two antibodies harboring $\mathrm{IgG}_{4}$ backbones, are approved for immune checkpoint blockade in the USA and the EU (43). The molecules effectively inhibited programmed cell death protein 1 /programmed cell death 1 ligand 1 (PD-1/PD-L1) interactions but were shown to be inactive eliciting Fc-mediated effector functions [reviewed in Topalian et al. (60)]. Another challenge in the development of $\mathrm{IgG}_{4}$-based therapeutic antibodies was the isotype's feature of the so-called Fab-arm exchange where single heavy chainlight chain dimers can form bivalent antibodies with other single heavy chain-light chain dimers (61). From a biological point of view it was discussed that the bivalency of $\mathrm{IgG}_{4}$ molecules may reduce their "pathological potential" (61). For certain applications, therapeutic antibody manufacturing can be challenging due to the Fab-arm exchange of $\operatorname{IgG}_{4}$. This led to the development of several antibody structure optimization strategies in the past $(59,61)$. A study published in 2009 showed that bispecific $\mathrm{IgG}_{4}$ antibodies were detectable in blood samples from patients who received an unmodified $\mathrm{IgG}_{4}$-based therapeutic antibody (62). The antibody formed half-molecules in vivo and furthermore, assembled to bispecific antibodies with patient-specific endogenous $\operatorname{IgG}_{4}$ (62). The group introduced a S228P amino acid substitution in the hinge-region of the antibody and showed the prevention of Fab-arm exchange impressively (62). The MAX.16H5 IgG 4 sequence was optimized in the same manner in order to prevent Fab-arm exchange (Figure 1) (56), to ensure the stability of the antibody, and the reliability of the manufacturing process during clinical development and GMP production.

\section{NON-CLINICAL DEVELOPMENT OF THE CHIMERIZED ANTI-HUMAN ANTI-CD4 ANTIBODY-STUDIES OF MAX.16H5 IgG AND $\operatorname{lgG}_{4}$ IN MURINE GVHD MODELS}

It was sought to examine the properties of the antibody's influence on the immune system using mouse models. To study the effect of the MAX.16H5 antibody against human CD4 expressing cells in mice, a genetically modified murine model with a C56BL/6 background was developed, which functionally expressed human $\mathrm{CD} 4$ on $\mathrm{T}$ cells while the murine $\mathrm{CD} 4$ gene was knocked-out (63-65). Additionally to the murine MHC II the T cells expressed human HLA-DR17 (63-65). In first experiments, spleen and lymph node samples of triple transgenic (TTG) mice previously immunized with tetanus toxoid (TT) showed reduced immune response after MAX.16H5 $\operatorname{IgG}_{1}$ treatment and re-stimulation with TT ex 


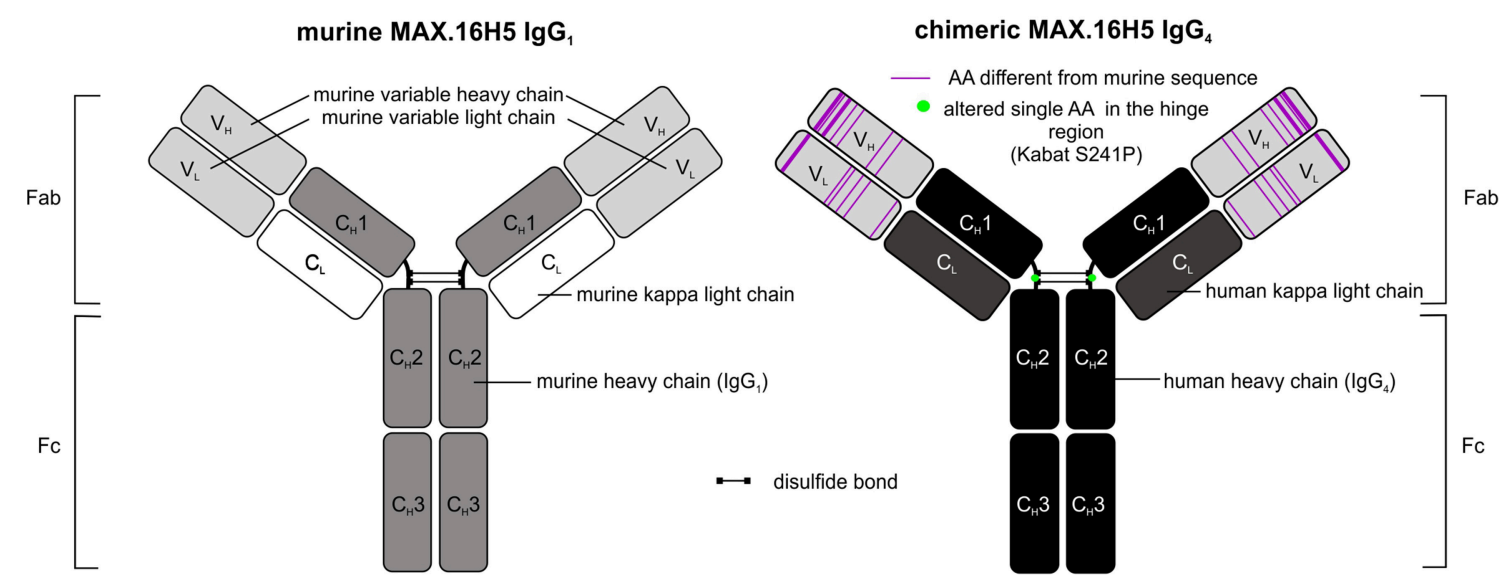

FIGURE 1 | Schematic representation of murine MAX.16H5 $\lg G_{1}$ and chimeric MAX.16H5 $\operatorname{lgG}_{4}$ antibodies.

vivo (66). The same effect emerged in vivo after injection with $15 \mu \mathrm{g} / \mathrm{g}$ body weight (BW) MAX.16H5 $\operatorname{IgG}_{1}$ (67) and the $\mathrm{F}(\mathrm{ab})_{2}$ of MAX.16H5 was as potent as the whole antibody (65). Surprisingly, unresponsiveness was preserved after the mice underwent another antigen boost without prior antibody administration, thus indicating a long-lasting but not depleting effect of MAX.16H5, which was moreover antigen-specific and dependent on the ability to form the immunological synapse between CD4 and HLA-DR (65). Therefore, we speculate, that MAX.16H5 does not induce a general immune suppression but only to antigens present simultaneously with or shortly after antibody treatment, most likely while the antibody is still bound to its ligand when the HLA-DR molecule encounters the TCR. This observation led to the idea that MAX.16H5 may conquer an old challenge in immunology: induction of specific tolerance and influencing both host-vs.-graft and graft-vs.-host reactions. The latter severely limit the application of allogeneic hematopoietic stem cell (HSC) and immune cell transplantations for the treatment of, e.g., autoimmune diseases or hematopoietic cancers such as leukemia.

Acute GVHD is the main complication of allogeneic hematopoietic stem cell transplantation (HSCT) and the main reason for early transplantation-associated mortality (68). Conventional immunosuppressive drugs such as corticosteroids are not specific and suppress the entire immune system (69). So far, no therapy manages HSCT or donor lymphocyte infusion without the need for conventional systemic immunosuppressive drugs. Promising in vivo data were obtained regarding the feasibility and effectivity of ex vivo graft incubation with MAX.16H5 IgG 1 and the antibody's influence on GVHD down modulation after allogeneic full-mismatch immune stem cell transplantation if the graft from TTG mice was preincubated with the antibody (70-72). Of note, removing unbound antibody molecules from the graft did not reduce its effectiveness (70-72). The graft's unresponsiveness to allogeneic $\mathrm{BALB} / \mathrm{c}^{\mathrm{wt}}$ antigens was even preserved if immune and stem cells from transplanted GVHD-free mice were transferred to new BALB/c $/ \mathrm{c}^{\mathrm{wt}}$ mice without MAX.16H5 preincubation-a phenomenon called "infectious tolerance" (71). This phenomenon is possibly achieved by heightened levels of $\mathrm{T}_{\text {regs }}$ present in mice receiving MAX.16H5-preincubated grafts suggesting a possible role for long-term unresponsiveness in vivo (71). Two studies did not only focus on accelerated GVHD but also on the maintained GVL effect mediated by the transplanted antibody incubated immune cell graft. To investigate the GVL effect mediated by the transplanted graft, $\mathrm{BALB} / \mathrm{c}^{\mathrm{wt}}$ animals did not only receive TTG immune cell grafts but also P815 cells, a murine mastocytoma cell line (70). It was shown that graft preincubation with the murine MAX.16H5 $\mathrm{IgG}_{1}$ antibody did not influence the GVL effect which was induced by the transplanted immune cells $(70,71)$. In another murine model, the murine MAX.16H5 $\mathrm{IgG}_{1}$ also prolonged the survival of recipient $\mathrm{C} 3 \mathrm{H} / \mathrm{HeN}$ mice (receiving a TTG immune cell graft to induce GVHD) even if they were co-transplanted with myeloblast-like murine cell line 32D Clone 3 (32D) expressing human Fms like tyrosine kinase 3 with the internal tandem repeat duplication (FLT3 ${ }^{\text {ITD }}$ ), which constitutes an aggressive acute myeloid leukemia (AML) cell line model (72).

The ex vivo graft incubation with MAX.16H5 together with a subsequent washing protocol was found to be an attractive and promising therapeutic setting in $\operatorname{HSCT}(31,70,71)$. It got even more into focus when patients, who received a therapeutic antibody, suffered from side-effects which were mainly caused by a systemic inflammatory response as a response to systemic application (73). In 2006, unpredicted sideeffects emerged during a phase-I (first-in-man) clinical trial with a CD28-directed monoclonal antibody called TGN1412 $(73,74)$. The antibody was developed to modulate $\mathrm{T}_{\text {reg }}$ expansion and was praised as "a promising novel tool for the treatment of human autoimmune diseases" (75). As of today, the cytokine release syndrome is a known sideeffect of different immunotherapeutic interventions such as therapeutic antibodies (e.g., CD20-directed mAbs, bispecific T cell engagers, and immune checkpoint inhibitors) or chimeric 


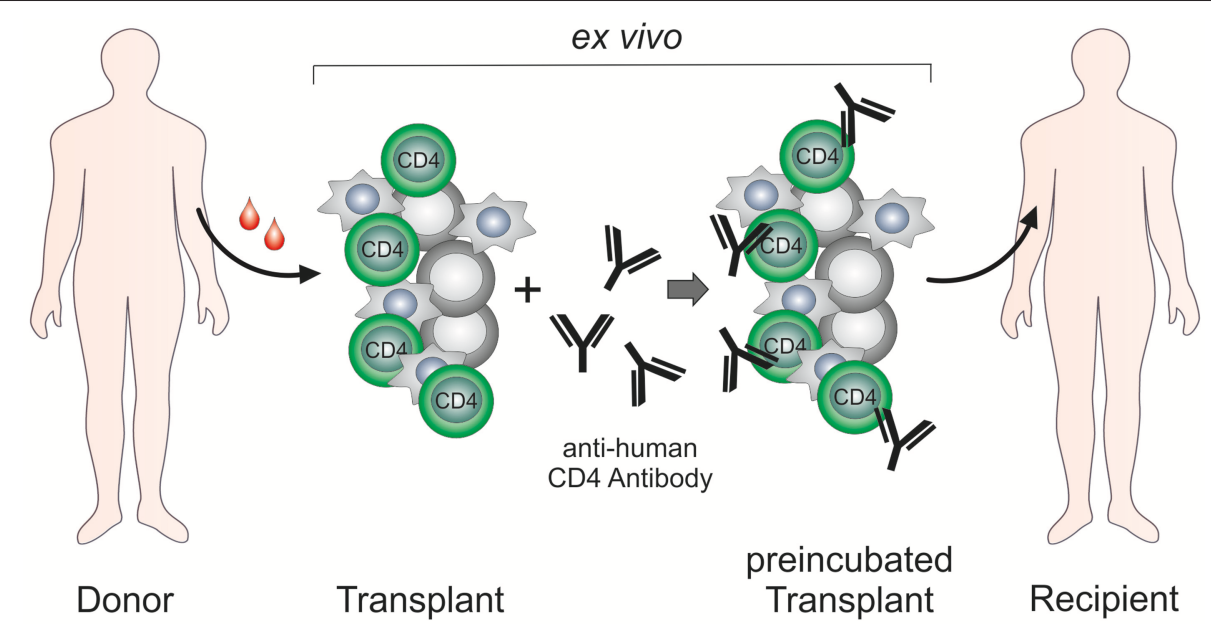

FIGURE 2 | EX vivo treatment of hematopoietic stem cell/immune cell grafts by anti-human CD4 antibody MAX.16H5.

antigen receptor (CAR) $\mathrm{T}$ cells [reviewed in ShimabukuroVornhagen et al. (76)]. Due to safety considerations, the development and optimization of the MAX.16H5 antibody format for the treatment of GVHD was shifted to ex vivo graft incubation rather than systemic administration of the therapeutic antibody.

After the chimerized MAX.16H5 $\mathrm{IgG}_{4}$ was available, its effectiveness in preventing GVHD was evaluated using a NOD.Cg-Prkdc scid $I l 2 r g^{t m 1 W j l} / S z J$ (NSG) mouse model (31). Here, mice received a xenogeneic human PBMC transplant to initiate acute GVHD (31). Both variants, the murine $\operatorname{IgG}_{1}$ and the chimeric $\mathrm{IgG}_{4}$ of the MAX.16H5 antibody, were compared regarding their ability to down regulate GVHD development. Unspecific isotype antibodies were used as controls in these experiments (31). The data were published in 2016 and showed that both the murine $\operatorname{IgG}_{1}$ and the chimerized $\mathrm{IgG}_{4}$ were able to prevent GVHD in this experimental setting (31). The mice received immune cell grafts which were ex vivo incubated with the respective antibodies making a systemic application of MAX.16H5 unnecessary. After $2 \mathrm{~h}$ of MAX.16H5 $\mathrm{IgG}_{1}$ or $-\mathrm{IgG}_{4}$ preincubation, the grafts were washed with PBS to remove excess, unbound antibodies. Finally $2 \times 10^{7}$ MAX.16H5 or isotype control treated graft cells were diluted in $150 \mu \mathrm{l} 0.9 \% \mathrm{NaCl}$ and were injected into the tail vein of the animals (31). Mice receiving MAX.16H5 murine $\operatorname{IgG}_{1}$ or chimeric $\operatorname{IgG}_{4}$ antibody incubated grafts showed a significant prolonged survival in comparison to mice receiving grafts incubated with isotype control antibodies (31). During these animal experiments, data were obtained collecting several parameters such as general health status (e.g., fur, weight, behavior, mobility), immune cell reconstitution (white blood cell counts, flow cytometric analyses of human T cell, B cell, and lymphocyte markers) and histological data (apoptotic cells in the gut of the mice, TUNEL) (31). Importantly, MAX.16 5 IgG $_{1}$ (murine) or $\mathrm{IgG}_{4}$ (chimeric) incubation of immune cell grafts comparably weakened GVHD development significantly but did not impair the engraftment of the transplanted cells (31).

\section{CONCLUDING REMARKS}

It was early known that even the murine $\mathrm{IgG}_{1}$ istoype of MAX.16H5 does not stimulate CDC or ADCC (13), but the mechanism of action is still not understood. Over the years of development, many theories have been arosen on its mechanism of action to induce tolerance. Despite being of interest, most data were not published as they showed negative results. Due to the quick responses observed in clinical trials, it was speculated that the antibody's mechanism was independent of antigen recognition which would take longer but was more likely caused by inhibition of preactivated IL-2-dependent T cells (32). However, this theory cannot explain why the antibody is effective in GVHD prevention after an ex vivo incubation, i.e., before the cells of the transplant had antigen contact. Moreover, the monocyte/macrophage system was thought to be involved, but this idea too was in conflict with reported data (13). Rising $\mathrm{T}_{\text {reg }}$ amounts in a murine model (71) are probably a mediator of tolerance but do not explain the mechanism how tolerance is achieved.

The majority of the studies performed with the antihuman CD4 antibody MAX.16H5 focused on the treatment of autoimmune diseases such as RA, SLE, IDB and JCA and revealed striking results that identified the MAX.16H5 antibody as a promising alternative for conventional therapeutics. Following initial systemic application of MAX.16H5, a new strategy was developed leading to similar success in therapy and improved safety of patients: graft $\mathrm{CD} 4^{+}$cells were incubated ex vivo with the MAX.16H5 antibody and re-infused into the patient (Figure 2). This innovative approach extended the scope from the treatment of autoimmune diseases to hematological malignancies. By ex vivo incubation of an allogeneic immuneand stem cell transplant with the epitope-specific anti-human CD4 antibody MAX.16H5, a new therapy strategy has emerged for the first time enabling both the preservation of the GVL effect of the transplant and the permanent suppression of GVHD without the need for conventional immunosuppression. 
The following essential benefits of this innovative therapeutic approach can be expected: First, the treatment of a human immune cell transplant does not deteriorate the anti-tumor effectiveness with regard to different leukemia types. Second, it is expected that an allogeneic HSC graft treated with MAX.16H5 anti-human CD4 antibodies leads to a general improvement of the survival due to suppression of the GVHD. Furthermore, the dosage and amount of conventional immunosuppressive drugs (toxicity, side effects, and duration of the treatment) can be reduced and the patients' quality of life could be improved. Due to the suppression of the GVHD, patients lacking a suitable donor will be applicable to receive donor cells whose transplantation normally would be associated with a higher risk for GVHD (e.g., more HLA mismatches). Thus, immune cell therapies will become applicable to cure other diseases (e.g., autoimmune diseases and primary immunodeficiencies) whose curative treatment regimen does currently not include this form of therapy because of a high risk for GVHD development. Finally yet importantly, the incubation of the allogeneic HSCT grafts with the epitope-specific anti-human CD4 antibody MAX.16H5 can be performed outside of the body which reduces side effects and therapy costs, antibody amounts as well as improves the safety of the transplantation remarkably.

\section{REFERENCES}

1. Knapp W, editor. Leucocyte Typing IV: White Cell Differentiation Antigens. Oxford: Oxford University Press (1989). p. 1182.

2. Sweet RW, Truneh A, Hendrickson WA. CD4: Its structure, role in immune function and AIDS pathogenesis, and potential as a pharmacological target. Curr Opin Biotechnol. (1991) 2:622-33. doi: 10.1016/0958-1669(91)9 0089-N

3. Wofsy D. Strategies for treating autoimmune disease with monoclonal antibodies. West J Med. (1985) 143:804-9.

4. Burmester GR, Horneff G, Emmrich F. Management of early inflammatory arthritis. Intervention with immunomodulatory agents: monoclonal antibody therapy. Baillieres Clin Rheumatol. (1992) 6:415-34.

5. Emmrich F, Kaufmann SH. Human T-cell clones with reactivity to Mycobacterium leprae as tools for the characterization of potential vaccines against leprosy. Infect Immun. (1986) 51:879-83.

6. Emmrich F, Hunsmann G, Lüke W. Monoclonal Antibody for Inhibiting Cell Infection by HIV Viruses (WO1990002199 A1). Google Patents (1989). Available online at: http://www.google.com/patents/WO1990002199A1?cl= en (accessed July 4, 2016).

7. Becker W, Emmrich F, Horneff G, Burmester G, Seiler F, Schwarz A, et al. Imaging rheumatoid arthritis specifically with technetium 99m CD4-specific (T-helper lymphocytes) antibodies. Eur J Nucl Med. (1990) 17:156-9.

8. Kearney JF, Radbruch A, Liesegang B, Rajewsky K. A new mouse myeloma cell line that has lost immunoglobulin expression but permits the construction of antibody-secreting hybrid cell lines. J Immunol. (1979) 123:1548-50.

9. Davis SJ, Schockmel GA, Somoza C, Buck DW, Healey DG, Rieber EP, et al. Antibody and HIV-1 gp120 recognition of CD4 undermines the concept of mimicry between antibodies and receptors. Nature. (1992) 358:76-9. doi: $10.1038 / 358076 \mathrm{a} 0$

10. Repke H, Gabuzda D, Palu G, Emmrich F, Sodroski J. Effects of CD4 synthetic peptides on HIV type I envelope glycoprotein function. J Immunol. (1992) 149:1809-16.

11. Becker W, Horneff G, Emmrich F, Burmester G, Kalden J, Wolf F. Kinetics of 99mTc-labelled antibodies against CD4 (T-helper) lymphocytes in man. Nuklearmedizin. (1992) 31:84-90.

\section{AUTHOR CONTRIBUTIONS}

LS, AD, NH, UT, and SF analyzed the publications, created the figures and tables, and wrote the paper.

\section{FUNDING}

This study was supported by the Fraunhofer Society, the Fraunhofer Cluster of Immune Mediated Diseases (CIMD), and the Leistungs- und Transferzentrum Chemieund Biosystemtechnik which is supported by Sächsische Aufbaubank (SAB).

\section{ACKNOWLEDGMENTS}

The authors thank the colleagues from the Fraunhofer Cluster of Immune Mediated Diseases (CIMD) for their helpful discussion and proof reading of the manuscript. Furthermore, we thank Prof. Dr. F. Emmrich for his valuable notes regarding the MAX.16H5 anti-human CD4 antibody. Study design, collection of data, analysis, decision to publish and preparation of the manuscript were not influenced.
12. Hiepe F, Volk HD, Apostoloff E, Baehr R von, Emmrich F. Treatment of severe systemic lupus erythematosus with anti-CD4 monoclonal antibody. Lancet. (1991) 338:1529-30.

13. Horneff G, Burmester GR, Emmrich F, Kalden JR. Treatment of rheumatoid arthritis with an anti-CD4 monoclonal antibody. Arthritis Rheum. (1991) 34:129-40.

14. Horneff G, Emmrich F, Kalden JR, Burmester GR. Suppression of monocytemacrophage activation by anti-CD4 therapy in patients with chronic polyarthritis. Immun Infekt. (1991) 19:55-6.

15. Horneff G, Krause A, Emmrich F, Kalden JR, Burmester GR. Elevated levels of circulating tumor necrosis factor-alpha, interferon-gamma, and interleukin-2 in systemic reactions induced by anti-CD4 therapy in patients with rheumatoid arthritis. Cytokine. (1991) 3:266-7.

16. Horneff G, Winkler T, Kalden JR, Emmrich F, Burmester GR. Human anti-mouse antibody response induced by anti-CD4 monoclonal antibody therapy in patients with rheumatoid arthritis. Clin Immunol Immunopathol. (1991) 59:89-103.

17. Horneff G, Emmrich F, Reiter C, Kalden JR, Burmester GR. Persistent depletion of CD4+ T cells and inversion of the CD4/CD8 T cell ratio induced by anti-CD4 therapy. J Rheumatol. (1992) 19:1845-50.

18. Horneff G, Sack U, Kalden JR, Emmrich F, Burmester GR. Reduction of monocyte-macrophage activation markers upon anti-CD4 treatment. Decreased levels of IL-1, IL-6, neopterin and soluble CD14 in patients with rheumatoid arthritis. Clin Exp Immunol. (1993) 91:207-13.

19. Emmrich F, Horneff G, Becker W, Luke W, Potocnik A, Kanzy U, et al. An anti-CD4 antibody for treatment of chronic inflammatory arthritis. Agents Actions Suppl. (1991) 32:165-70.

20. Emmrich J, Seyfarth M, Fleig WE, Emmrich F. Treatment of inflammatory bowel disease with anti-CD4 monoclonal antibody. Lancet. (1991) 338:570-1.

21. Horneff G, Dirksen U, Schulze-Koops H, Emmrich F, Wahn V. Treatment of refractory juvenile chronic arthritis by monoclonal CD4 antibodies: a pilot study in two children. Ann Rheum Dis. (1995) 54:846-9.

22. Reinke P, Volk HD, Miller H, Neuhaus K, Fietze E, Herberger J, et al. AntiCD4 therapy of acute rejection in long-term renal allograft recipients. Lancet. (1991) 338:702-3.

23. Kinne RW, Becker W, Schwab J, Horneff G, Schwarz A, Kalden JR, et al. Comparison of 99Tcm-labelled specific murine anti-CD4 monoclonal 
antibodies and non-specific human immunoglobulin for imaging inflamed joints in rheumatoid arthritis. Nucl Med Commun. (1993) 14:667-75.

24. Kinne RW, Becker W, Schwab J, Schwarz A, Kalden JR, Emmrich F, et al. Imaging rheumatoid arthritis joints with technetium-99m labelled specific anti-CD4- and non-specific monoclonal antibodies. Eur J Nucl Med. (1994) 21:176-80.

25. Courtenay-Luck NS, Epenetos AA, Moore R, Larche M, Pectasides D, Dhokia B, et al. Development of primary and secondary immune responses to mouse monoclonal antibodies used in the diagnosis and therapy of malignant neoplasms. Cancer Res. (1986) 46(12 Pt 1):6489-93.

26. Schroff RW, Foon KA, Beatty SM, Oldham RK, Morgan AC, JR. Human antimurine immunoglobulin responses in patients receiving monoclonal antibody therapy. Cancer Res. (1985) 45:879-85.

27. Bruhns P. Properties of mouse and human IgG receptors and their contribution to disease models. Blood. (2012) 119:5640-9. doi: 10.1182/blood-2012-01-380121

28. Neuberger MS, Rajewsky K. Activation of mouse complement by monoclonal mouse antibodies. Eur J Immunol. (1981) 11:1012-6. doi: 10.1002/eji.1830111212

29. Ey PL, Russell-Jones GJ, Jenkin CR. Isotypes of mouse IgG-I. Evidence for 'non-complement-fixing' IgG1 antibodies and characterization of their capacity to interfere with IgG2, sensitization of target red blood cells for lysis by complement. Mol Immunol. (1980) 17:699-710. doi: 10.1016/0161-5890(80)90139-X

30. Michaelsen TE, Kolberg J, Aase A, Herstad TK, Høiby EA. The four mouse IgG isotypes differ extensively in bactericidal and opsonophagocytic activity when reacting with the P1.16 epitope on the outer membrane PorA protein of Neisseria meningitidis. Scand J Immunol. (2004) 59:34-9. doi: 10.1111/j.0300-9475.2004.01362.x

31. Hilger N, Glaser J, Muller C, Halbich C, Muller A, Schwertassek U, et al. Attenuation of graft-versus-host-disease in NOD scid IL-2Rgamma-/- (NSG) mice by ex vivo modulation of human CD4+ T cells. Cytometry A. (2016) 89:803-15. doi: 10.1002/cyto.a.22930

32. Bröker BM, Yu A, Tsygankov AY, Fickenscher H, Chitaev NA, MüllerFleckenstein I, et al. Engagement of the CD4 receptor inhibits the interleukin2-dependent proliferation of human $\mathrm{T}$ cells transformed byHerpesvirus saimiri. Eur. J. Immunol. (1994) 24:843-50. doi: 10.1002/eji.1830240411

33. Horneff G, Guse AH, Schulze-Koops H, Kalden JR, Burmester GR, Emmrich F. Human CD4 modulation in vivo induced by antibody treatment. Clin Immunol Immunopathol. (1993) 66:80-90.

34. Guse AH, Tsygankov A, Broker BM, Roth E, Emmrich F. Signal transduction in $\mathrm{T}$ lymphocytes and monocytes: effects of the anti-CD4 antibody MAX.16H5. Year Immunol. (1993) 7:175-81.

35. Shevach EM. Regulatory T cells in autoimmmunity*. Annu. Rev. Immunol. (2000) 18:423-49. doi: 10.1146/annurev.immunol.18.1.423

36. Sakaguchi S. Regulatory T Cells. Cell. (2000) 101:455-8. doi: 10.1016/S0092-8674(00)80856-9

37. Fontenot JD, Gavin MA, Rudensky AY. Foxp3 programs the development and function of CD4+CD25+ regulatory T cells. Nat Immunol. (2003) 4:330-6. doi: 10.1038/ni904

38. Hori S, Nomura T, Sakaguchi S. Control of regulatory T cell development by the transcription factor Foxp3. Science. (2003) 299:1057-61. doi: 10.1126/science.1079490

39. Khattri R, Cox T, Yasayko S-A, Ramsdell F. An essential role for Scurfin in CD4+CD25+ T regulatory cells. Nat Immunol. (2003) 4:337. doi: $10.1038 /$ ni 909

40. Wang J, Yan T, Simmer B, Emmrich F. The effect of anti-CD4 on helper function of CD4,45RA+ versus $\mathrm{CD} 4,45 \mathrm{RO}+\mathrm{T}$ cells. Clin Exp Immunol. (1994) 95:128-34.

41. Lourenço EV, La Cava A. Cytokines in systemic lupus erythematosus. Curr Mol Med. (2009) 9:242-54.

42. McInnes IB, Schett G. Cytokines in the pathogenesis of rheumatoid arthritis. Nat Rev Immunol. (2007) 7:429-42. doi: 10.1038/nri2094

43. The Antibody Society. Approved Antibodies. (2015) Available online at: https://www.antibodysociety.org/news/approved-antibodies/ (accessed March 19, 2018).

44. Heinrich PC, Castell JV, Andus T. Interleukin-6 and the acute phase response. Biochem J. (1990) 265:621-36.
45. Chatenoud L, Ferran C, Reuter A, Legendre C, Gevaert Y, Kreis H, et al. Systemic reaction to the anti-T-cell monoclonal antibody OKT3 in relation to serum levels of tumor necrosis factor and interferon-gamma corrected. $N$ Engl J Med. (1989) 320:1420-1. doi: 10.1056/NEJM198905253202117

46. Suthanthiran M, Fotino M, Riggio RR, Cheigh JS, Stenzel KH. OKT3associated adverse reactions: mechanistic basis and therapeutic options. Am J Kidney Dis. (1989) 14(5 Suppl. 2):39-44.

47. Brink I, Thiele B, Burmester GR, Trebeljahr G, Emmrich F, Hiepe F. Effects of anti-CD4 antibodies on the release of IL-6 and TNF-alpha in whole blood samples from patients with systemic lupus erythematosus. Lupus. (1999) 8:723-30.

48. Burmester GR, Emmrich F. Anti-CD4 therapy in rheumatoid arthritis. Clin Exp Rheumatol. (1993) 11(Suppl. 8):45.

49. Guse AH, Roth E, Broker BM, Emmrich F. Complex inositol polyphosphate response induced by co-cross-linking of $\mathrm{CD} 4$ and $\mathrm{Fc}$ gamma receptors in the human monocytoid cell line U937. J Immunol. (1992) 149:2452-8.

50. Horneff G, Burmester GR, Strobel G, Gramatzki M, Kalden JR, Emmrich F. Therapie der chronischen Polyarthritis mit einem monoklonalen Antikörper gegen das CD4-Antigen auf T-Helferzellen. Aktuelle Rheumatol. (1989) 1989:232.

51. Reiter C, Kakavand B, Rieber EP, Schattenkirchner M, Riethmuller G, Kruger $\mathrm{K}$. Treatment of rheumatoid arthritis with monoclonal CD4 antibody MT151. Clinical results and immunopharmacologic effects in an open study, including repeated administration. Arthritis Rheum. (1991) 34:525-36.

52. Nadler LM, Stashenko P, Hardy R, Kaplan WD, Button LN, Kufe DW, et al. Serotherapy of a patient with a monoclonal antibody directed against a human lymphoma-associated antigen. Cancer Res. (1980) 40:3147-54.

53. Morrison SL, Johnson MJ, Herzenberg LA, Oi VT. Chimeric human antibody molecules: mouse antigen-binding domains with human constant region domains. Proc Natl Acad Sci. (1984) 81:6851-5.

54. McLaughlin P, Grillo-López AJ, Link BK, Levy R, Czuczman MS, Williams $\mathrm{ME}$, et al. Rituximab chimeric anti-CD20 monoclonal antibody therapy for relapsed indolent lymphoma: half of patients respond to a four-dose treatment program. J Clin Oncol. (1998) 16:2825-33. doi: 10.1200/JCO.1998.16.8.2825

55. Greig SL. Obiltoxaximab: first global approval. Drugs. (2016) 76:823-30. doi: 10.1007/s40265-016-0577-0

56. Fricke S, Emmrich F, Hilger N. Anti-CD4 Antibodies to Prevent in Particular GRAFT-versus-Host Disease (GvHD): US Patent (US 9,745,552 B2) (2011).

57. Wang $\mathrm{X}$, Mathieu $M$, Brezski RJ. IgG $F c$ engineering to modulate antibody effector functions. Protein Cell. (2017) 9:63-73. doi: 10.1007/s13238-017-0473-8

58. Brüggemann M, Williams GT, Bindon CI, Clark MR, Walker MR, Jefferis R, et al. Comparison of the effector functions of human immunoglobulins using a matched set of chimeric antibodies. J Exp Med. (1987) 166:1351-61.

59. Davies AM, Sutton BJ. Human IgG4: a structural perspective. Immunol Rev. (2015) 268:139-59. doi: 10.1111/imr.12349

60. Topalian SL, Drake CG, Pardoll DM. Targeting the PD-1/B7-H1(PD-L1) pathway to activate anti-tumor immunity. Curr Opin Immunol. (2012) 24:207-12. doi: 10.1016/j.coi.2011.12.009

61. Aalberse RC, Schuurman J. IgG4 breaking the rules. Immunology. (2002) 105:9-19. doi: 10.1046/j.0019-2805.2001.01341.x

62. Labrijn AF, Buijsse AO, van den Bremer ET, Verwilligen AY, Bleeker WK, Thorpe SJ, et al. Therapeutic IgG4 antibodies engage in Fab-arm exchange with endogenous human IgG4 in vivo. Nat Biotechnol. (2009) 27:767-71. doi: $10.1038 /$ nbt. 1553

63. Laub R, Dorsch M, Wedekind D, Meyer D, Schröder S, Ermann J, et al. Replacement of murine by human CD4 and introduction of HLA-DR17 in mice: a triple-transgenic animal model to study human MHC II-CD4 interaction in situ. J Exp Anim Sci. (1999) 39:122-35.

64. Meyer D, Laub R, Dorsch M, Thamm B, Ermann J, Lehmann J, et al. Replacement of murine by human CD4 and introduction of HLA-DR in mice: a triple-transgenic animal model to study human MHC II-CD4 interaction in situ. In: 28th Annual Meeting of the Deutsche Gesellschaft für Immunologie. September 24-27, 1997. Abstracts. Elsevier GmbH (1997). p. 153.

65. Laub R, Brecht R, Dorsch M, Valey U, Wenk K, Emmrich F. Anti-human CD4 induces peripheral tolerance in a human CD4+, murine CD4-, HLADR+ advanced transgenic mouse model. J Immunol. (2002) 169:2947-55. doi: $10.4049 /$ jimmunol.169.6.2947 
66. Laub R, Dorsch M, Meyer D, Ermann J, Hedrich HJ, Emmrich F. A multiple transgenic mouse model with a partially humanized activation pathway for helper T cell responses. J Immunol Methods. (2000) 246:37-50. doi: 10.1016/S0022-1759(00)00288-X

67. Laub R, Dorsch M, Wenk K, Emmrich F. Induction of immunologic tolerance to tetanus toxoid by anti-human CD4 in HLA-DR3(+)/human CD4(+)/murine CD4(-) multiple transgenic mice. Transplant Proc. (2001) 33:2182-3. doi: 10.1016/S0041-1345(01)01934-0

68. Holtan SG, Pasquini M, Weisdorf DJ. Acute graft-versus-host disease: a bench-to-bedside update. Blood. (2014) 124:363-73. doi: 10.1182/blood-2014-01-514786

69. Garnett C, Apperley JF, Pavlu J. Treatment and management of graft-versus-host disease: improving response and survival. Ther Adv Hematol. (2013) 4:366-78. doi: 10.1177/20406207134 89842

70. Schmidt F, Hilger N, Oelkrug C, Svanidze E, Ruschpler P, Eichler W, et al. Flow cytometric analysis of the graft-versus-Leukemia-effect after hematopoietic stem cell transplantation in mice. Cytometry A. (2015) 87:33445. doi: 10.1002/cyto.a.22619

71. Fricke S, Hilger N, Fricke C, Schonfelder U, Behre G, Ruschpler P, et al. Prevention of graft-versus-host-disease with preserved graft-versus-leukemiaeffect by ex vivo and in vivo modulation of CD4(+) T-cells. Cell Mol Life Sci. (2014) 71:2135-48. doi: 10.1007/s00018-013-1476-0

72. Hilger N, Mueller C, Stahl L, Mueller AM, Zoennchen B, Dluczek S, et al. Incubation of immune cell grafts with MAX.16H5 IgG1 anti-human CD4 antibody prolonged survival after hematopoieticstem cell transplantation in a mouse model for Fms like tyrosine kinase 3 positive acute myeloid leukemia. Front. Immunol. (2018) 9:1131. doi: 10.3389/fimmu.2018.02408

73. Suntharalingam G, Perry MR, Ward S, Brett SJ, Castello-Cortes A, Brunner $\mathrm{MD}$, et al. Cytokine storm in a phase 1 trial of the antiCD28 monoclonal antibody TGN1412. N Engl J Med. (2006) 355:1018-28. doi: 10.1056/NEJMoa063842

74. Pearson H. Tragic drug trial spotlights potent molecule. Nature. (2006). doi: 10.1038/news060313-17

75. Beyersdorf N, Hanke T, Kerkau T, Hünig T. CD28 superagonists put a break on autoimmunity by preferentially activating $\mathrm{CD} 4+\mathrm{CD} 25+$ regulatory $\mathrm{T}$ cells. Autoimmun Rev. (2006) 5:40-5. doi: 10.1016/j.autrev.2005.06.001

76. Shimabukuro-Vornhagen A, Gödel P, Subklewe M, Stemmler HJ, Schlößer HA, Schlaak M, et al. Cytokine release syndrome. J Immunother Cancer. (2018) 6:56. doi: 10.1186/s40425-018-0343-9

Conflict of Interest Statement: The authors declare that the research was conducted in the absence of any commercial or financial relationships that could be construed as a potential conflict of interest.

Copyright (C) 2019 Stahl, Duenkel, Hilger, Tretbar and Fricke. This is an open-access article distributed under the terms of the Creative Commons Attribution License (CC $B Y)$. The use, distribution or reproduction in other forums is permitted, provided the original author(s) and the copyright owner(s) are credited and that the original publication in this journal is cited, in accordance with accepted academic practice. No use, distribution or reproduction is permitted which does not comply with these terms. 